\title{
COMPARING RELIGIOUS EDUCATION IN INDONESIA AND JAPAN
}

\author{
M. Agus Nuryatno \\ Sunan Kalijaga State Islamic University, Yogyakarta, Indonesia \\ email:agusnuryatno@yahoo.com
}

\begin{abstract}
This paper compares the way in which religious education has been performed in Indonesia and Japan in terms of context, theory, history, policy, practice, and impact. Generally speaking, the practice of religious education in the two countries is far different in that Indonesia bas strong support to religious education, while Japan has weak support to the practice of religious education. This is due to the fact that not only the characteristics of the societies of the two countries are different, but also the two do embrace different state's ideology. In addition families in the two societies play a crucial role in determining the existence and practice of religious education.

Tulisan ini membandingkan pengajaran agama antara Indonesia dan Jepang dalam hal konteks, teori, sejarah, kebijakan, dan pengarubnya. Secara umum dapat dikatakan babwa pendidikan agama di kedua negara ini sangat berbeda. Di Indonesia, pemerintah memberikan dukungan besar terbadap pendidikan agama, sementara pemerintah Jepang sangat kurang mendukung pendidikan agama. Hal ini tidak, hanya dikarenakan karakter masyarakat dari kedua negara ini yang sangat berbeda, tetapi juga disebabkan ideologi dari kedua negara ini yang juga berbeda. Terlepas dari itu, di kedua negara ini lembaga keluarga memiliki peran yang cukup krusial dalam menentukan eksistensi dan pelaksanaan pendidikan agama.]
\end{abstract}

Keywords: religious education, state ideology, state policy, private school, public school 


\section{Agus Nuryatno}

\section{A. Introduction}

It is worth noting that with regard to religion and education policy and ideology vary from one country to another in the world. Countries that embrace secular ideology, such as the United State, Japan, South Korea, Mexico, Uruguay, Cuba, Azerbaijan and Kazakhstan, do not allow religious education held in public schools, but they do allow so in private schools. By contrast, Indonesia supports religious education in public schools. Moreover, the state officially demands religious education as part of school's curricula. Other countries whose societies are attached to religious tradition, such as Pakistan ${ }^{1}$ and Malaysia, ${ }^{2}$ share this policy.

In short, the practice of religious education (RE) in a country depends on the state's ideology. There are some models of the relation of RE and state's ideology. ${ }^{3}$ First, when the state ideology is secular RE is prohibited in public schools, but not in private schools. This model can be seen in the United States, Japan, South Korea, Mexico, Uruguay, and Cuba. Secondly, although the state's ideology is secular, the majority of population belongs to certain religious tradition (Catholic, for example), $\mathrm{RE}$ is allowed in both public and private schools. This practice can be seen in Austria, Germany, Spanish, Columbia, Chili, and Peru. Exceptional is in the cases of two former Soviet Union countries, Azerbaijan and Kazakhstan, which choose secular ideology, but the majority of their populations are Muslims; they do not allow religious education taught in public schools. The third model is that when state's ideology belongs to certain religion, like Islam, RE is not only permitted but is also required as part of public schools' curricula. In this case RE specifically refers to Islamic education, which consequently implies that RE in public schools refers to Islamic education. This is what happens in Pakistan and Malaysia both of which hold Islam as formal states' religion. The fourth model is when the state's ideology is neither secular nor religion, like Indonesia,

${ }^{1}$ Khalil-ur-Rehman Khan and Qaisar Javed Mian, "Religious Education in Pakistan", in The Routledge International Handbook of Religious Education, ed. by Derek Davis and Elena Miroshnikova (New York: Routledge, 2013), pp. 251-55.

2 Rosnani Hashim, "Religious Education in Malaysia", in The Routledge International Handbook of Religious Education, ed. by Derek H. Davis and Elen Miroshnikova (New York: Routledge, 2013), pp. 217-26.

${ }^{3}$ Derek H. Davis and Elen Miroshnikova (eds.), The Routledge International Handbook of Religious Education (New York: Routledge, 2013). This is the most comprehensive book discusses the practice of religious education in fifty three countries, from the East to the West, from the South to the North, or from secular to religious-based state. 
$\mathrm{RE}$ is not only permitted but also required in public and private schools. However, the content of RE in the fourth model is not only about Islamic teachings, but also those of other religions acknowledged by the state of Indonesia.

This paper compares religious education in Indonesia and Japan in terms of social context, state's policy, history, RE in schools, and students' behaviors. This study tries to answer a question as to why the RE which has strong support from state, family, and religious institutions has little impact on students' good behaviors. On the other hand, students in secular countries, such as in Japan, who do not receive RE at all are not necessarily worse in behavior than students with $\mathrm{RE}$ in religious societies.

\section{B. Indonesia and Japan in Comparison}

To compare Indonesia and Japan, Indonesia has population around 242.3 million, ${ }^{4}$ whereas Japan has 126.66 million. ${ }^{5}$ The state's ideology of Indonesia is Pancasila ${ }^{6}$; while Japan adopts secular ideology. It seems that different state's ideology contributes to different practices of RE. ${ }^{7}$ In Indonesia with the Pancasila as the state's ideology, religion plays a crucial role in the country. ${ }^{8}$ There are six religions acknowledged officially by

4 This number is based on the "Indonesia Population 2013", World Population Statistics (12 Jun 2013), http://www.worldpopulationstatistics.com/indonesiapopulation-2013/, accessed 18 Feb 2014.

5 This number is based on the "Japan Population 2013", World Population Statistics (27 Sep 2013), http://www.worldpopulationstatistics.com/japan-population-2013/, accessed 18 Feb 2014.

${ }^{6}$ Pancasila is neither secular nor Islamic ideology, but somewhere between the two. The Indonesian founding fathers chose this ideology because it could accommodate and become a meeting point between two different ideologies: Islam and secular ideology. The name of Pancasila itself has secular nuance, but its principles contains religious nuance, particularly the first principle "Belief in One God," and this first principle becomes the foundation of the other four principles: humanity, unity in diversity, democracy, and justice.

7 Davis and Miroshnikova (eds.), The Routledge International Handbook, p. 5.

${ }^{8}$ It is going to be easy to proof how religion plays a significant role in people life. Each year Indonesia send more than two hundred thousand pilgrimages to Mecca and millions are on the waiting list to go. Many religious organizations can be found easily in this country with Nahdhatul Ulama and Mubammadiyah as the biggest ones. The former have thousands of Pesantren (Islamic boarding school), while the latter have thousands of Islamic schools, from kindergarten up to higher education. To some extent, the face of Islam in Indonesia depends on these two organizations. Places of worship such as mosques, churches, synagogues, and the like, are easy to find, anywhere and everywhere. Thus, Indonesia and religion is looked like two sides on the same coin Al-Jämi'ah, Vol. 52, No. 2, 2014 M/1435 H 


\section{Agus Nuryatno}

the state: Islam (87.2\%), Christianity (7\%), Hinduism (1.7\%), Buddhism $(0.9 \%)$, and Confucianism. In Japan, which chose secular ideology as the foundation of the nation, religion plays no significant role in the country. There is no mention of official religion in Japan, although Article 20 of its Constitution guarantees religious freedom. ${ }^{9}$ Nor is there official statistic which explains the affiliation of the population of Japan to which religion. However, according to International Religious Freedom Report published in 2013, based on 2011 report by the government's Agency for Cultural Affairs (ACA) indicates that some religious groups claim that their members reached 196 millions. This number, ironically more than the number of country's population, indicates that many citizens show affiliation with multiple religions; and it is common for Japanese to embrace both Buddhist and Shinto beliefs at the same time. ${ }^{10}$ However, according to Edwin Reischauer and Marius Jansen, 70-80\% of the Japanese do not consider themselves believers in any religion. ${ }^{11}$

Indonesia's population is diverse not only in terms religions, but also ethnicities, languages, and cultures. ${ }^{12}$ This country has around 300 distinct native ethnic groups and 742 different languages and dialects. The largest ethnic group is Javanese, comprising $42 \%$ of the population, and are politically and culturally dominant. In terms of language, the official language is Bahasa Indonesia, and it is a compulsory lesson taught in schools, from elementary to higher education. In fact, people speak one of several hundred local languages and dialects, and of these, Javanese language is the most widely spoken as the language of the largest ethnic group. By contrast, Japanese culture shows more homogeneous in terms of linguistic and culture, ${ }^{13}$ as $98.5 \%$ of its population speak Japanese,

that inseparable.

9 See more detail on chapter "State Policy on RE".

10 "International Religious Freedom Report for 2013", U.S. Department of State (15 Sep 2013), http://www.state.gov/j/drl/rls/irf/religiousfreedom/index.htm, accessed 18 Feb 2014.

11 Ibid.

12 To know more about Indonesia, some books in English are available, among others, are: Merle Calvin Ricklefs, A History of Modern Indonesia Since c.1200, 4th edition (Stanford, California: Stanford University Press, 2008); Tineke Hellwig and Eric Tagliacozzo (eds.), The Indonesia Reader: History, Culture, Politics (Durham: Duke University Press, 2009); Jean Gelman Taylor, Indonesia: Peoples and Histories (New Haven: Yale University Press, 2003).

${ }^{13}$ Chris Burgess, "Multicultural Japan Remains a Pipe Dream", The Japan Times (27 Mar 2007), http:/ /www.japantimes.co.jp/community/2007/03/27/issues/ multicultural-japan-remains-a-pipe-dream/, accessed 16 Jan 2013. 
whereas the rests are small minority groups, such as Zainichi Korea, Zainichi Chinese, Filipinos, Brazilians (mostly Japanese descent), and Peruvians (mostly Japanese descent). Former Japanese Prime Minister Taro Aso once declared that Japan is a nation of "one race, one civilization, one language, and one culture."14

\section{RE: Theoretical Perspective}

Michael Grimmit distinguished three meanings of religious education, namely learning religion, learning from religion and learning about religion. ${ }^{15}$ Religious education $(\mathrm{RE})$ as learning religion means the transmission of religious culture, belief, and values from one generation to another generation. The function of religious education is thus to perpetuate, and to hand on, religious values and tradition in society. In learning religion model students are treated as passive beings, because their position is only to receive and accept religious teachings and values from teachers. The process of transmission and transfer of these religious values is through indoctrination.

The model of RE as learning from religion looks for advantages of the religion for human life. How could religion possibly contribute to solve the problems faced by human beings? What are the values of religion for human life? The RE is defined in learning from religion as that learner holds positive attitude toward RE. The emphasis of RE is to seek what values of religions which can be employed to solve human problems in changing society. In this regard, there will be no critical judgment of religion, because religion is treated as a source of knowledge and moral principles.

Religious education as learning about religion means studying religion in a purely objective and descriptive manner, not merely absorbing or receiving religious values. This approach can be called as an objective form of teaching religion. $\mathrm{RE}$ as learning about religion has contribution to treat religion with either criticism or appreciation. Learner has to take distance from religion, because it is an object of study. In this vein, RE is carried out through scientific and dialogical ways, and critical thinking

${ }^{14}$ Kyodo, "Aso says Japan is Bation of 'One Race", The Japan Times Online (18 Oct 2005), http:/ /www.japantimes.co.jp/news/2005/10/18/national/aso-says-japanis-nation-of-one-race/, accessed 16 Jan 2013.

${ }_{15}$ Michael Grimmitt, Religious Education and Human Development: The Relationship between Studying Religions and Personal, Social and Moral Education (Great Britain: McCrimmons Publishing, 1987), pp. 67-8. 


\section{Agus Nuryatno}

is necessary in this model of RE.

Looking at the above theoretical perspectives, the practice of RE in Indonesia is dominated by learning religion and learning from religion, particularly in the elementary and secondary junior and senior high schools. In the higher education level, these two models are still dominant, with exception in higher education which specialization in religious studies, in which religion is not only seen as a doctrine that should be accepted blindly, but is also as knowledge which can be criticized. In Japan, the practice of $\mathrm{RE}$ is closer to the model of learning religion and learning from religion for private religious-based schools. The public schools use the model of learning about religion, which can be seen in the subject of history (Japanese History and World History), ethics (talking about many religions), and moral education.

\section{State's Policy on RE}

The social context of Indonesia where religion plays a significant role in public life helps us to understand why RE in this country is strongly supported by the state. RE is not only permitted, but required, to be taught in public and private schools, from elementary to higher education. ${ }^{16}$ In Japan, the state keeps distance from religion, because the country is based on secular ideology. As a result, RE is not allowed to be taught in public schools, but is allowed in private schools. From this perspective, the relation between the choice of state's ideology and the way in which RE is carried out is connected.

There are three articles on religious education mentioned in the bill of Republic of Indonesia number 20 year 2003 about National Education System. Article 12, point 1 (a), states that "Each student in the unit of education has rights to: (a) receive religious education in his/her own faith which is taught by a teacher of that faith." 17 Public schools do not have problem with this article, because they are used to teach religion

${ }^{16}$ Since Islam is not the ideology of the state, the content of RE is not only Islamic teachings, but also Christianity (Protestant and Catholic), Hinduism, Buddhism, and Confucianism. However, each religion is taught separately based on the faith of students and taught by a teacher of that faith. Compare to RE in Malaysia and Pakistan, $\mathrm{RE}$ in Indonesia is more pluralist and multiculturalists. In Malaysia and Pakistan, for example, the content of RE at public schools are only those of Islamic teachings, because both countries based on Islamic ideology; see: Eiichiro Takahata, "Religious Education in Japan", in The Routledge International Handbook of Religious Education, ed. by Derek H. Davis and Elena Miroshnikova (New York: Routledge, 2013), pp. 251-55.

17 The Bill of Education No. 20 Year 2003 on National Education System. 
in this way. However, for private schools, particularly of those that is based on certain religion, this article is controversial, for two reasons: first, this article is not in line with the right of community to hold education based on the faith of that community, and secondly, it is a big burden for these schools to provide religious teachers outside the faith embraced by these schools. ${ }^{18}$ In many cases, private schools based on Christianity have more Muslim students than Christians. The reason of why some Muslim families send their children to Christian schools is not because of religion, but a consideration of the school's quality. Christian schools are perceived to show good quality in terms of education. In practical level, article 12 is not yet implemented fully, and even some Christian schools choose not to hold a regular religious education, but they replace it with religiosity education or communication of faith. ${ }^{19}$

There are two other articles in the bill of RI no. 20 year 2003 that have relation to religious education, namely article 30 and article 37. Article 30 deals with religious education in terms of (a) the holder of religious education; (b), the function of religious education; (c) the content of education that hold religious education, and (d) the forms of religious education. ${ }^{20}$ Article 37 talks about religious education that should become elements of national curriculum for elementary, secondary, and higher education levels. The three articles 12, 30, and 37 of the bill of RI no. 20 year 2003 elaborate in details the government regulation no. 55 year 2007 containing six chapters and fifty articles. Article 4, points 5 and 6, states "Every unit of education provides place and opportunity for students to perform religious service based on their religion" and

18 The second problem actually have been anticipated by making cooperation with local government as mentioned in the Government Regulation No. 55 Year 2007 Article 6 that states "If the unit of education could not provide teachers of religious education then the central government and/or local government obliged to provide them in accordance with the need of unit of education."

19 Religiosity education or communication of faith is a notion derived from Romo Mangunwijaya in combination with practical pedagogy at Ignasius Loyola, Semarang. The exact definition of religiosity education is: "communication of faith among students of the same or different faith concerning their live experiences that been exposed its meaning, so that they are helped to become the whole person (religiously, morally, openness), and expected to become subjects of social transformation, for the sake of the creation of collective prosperity." See: Listia, Laode Arham, and Lian Gogali, Problematika Pendidikan Agama di Sekolah: Hasil Penelitian tentang Pendidikan Agama di Kota Jogjakarta 2004-2006 (Yogyakarta: Dian Interfidei, 2004), p. 151.

20 The Bill of RI Number 20 Year 2003 about National Education System, Article 30 and 37. 


\section{Agus Nuryatno}

"Place for worship as mentioned in the article (5) could be in the form of room in or around the unit of education that can be used by students to perform religious services."

The above policies show clearly the strong support of the state to $\mathrm{RE}$ in Indonesia. Not only is RE included in the bill of RI no. 20 year 2003 indicating that RE is a part of national education system, but it also explains in details the content of government's regulation no. 55 year 2007. In contrast, Japan does not allow RE to be taught in public schools, but is allowed in private schools. There are only two articles concerning RE in the Japanese Constitution, one is found in the Japanese Constitution, article $20^{21}$, and another article is found in the Basic Act on Education 2006, Article 15. ${ }^{22}$

The Japanese Constitution, article 20, states:

"Freedom of religion is guaranteed to all; No religious organizations shall receive any privileges from the State, nor exercise any political authority; No person shall be compelled to take part in any religious acts, celebration, rite or practice; The State and its organs shall refrain from religious education or any other religious activity."

The Basic Act on Education 2006, article 15, states:

The attitude of religious tolerance, general knowledge regarding religion, and the position of religion in social life shall be valued in education.

The schools established by the national and local governments shall refrain from religious education or other activities for a specific religion.

The Japanese Constitution, article 20, do not purely talks about RE, but it does so about religion in general. The content of article 20 can be divided into several issues: first, freedom of religion is protected. Anybody is free to follow or not to follow any belief or religion. Changing religion is part of human right protected and guaranteed by the Constitution. According to the International Religious Freedom Report 2013, released by the US Department of State, Japan is acknowledged as a country that consistently protects religious freedom, not only mentioned in the Japanese Constitution but also in practice it does. ${ }^{23}$ The second issue in the article 20 is about freedom of religious organizations. Establishing religious organization is guaranteed by the constitution, but the government does not provide financial support, because the state should

${ }^{21}$ The Japanese Constitution, Article 20.

22 The Basic Act of Education, 2006, Article 15.

${ }^{23}$ See "International Religious." 
keep its neutrality from any kind of religious organization. At this point, religious organization is not allowed to take part in the political activity. Another issue in the above article is about individual freedom to religion, namely to participate or not to participate in certain religious practices is an individual's choice and freedom, and nobody can force somebody else to take part or not to certain religious practices. The last statement "the State and its organs shall refrain from religious education" means that religious education is prohibited in public schools, and this is in line with the Japanese Constitution which guards the separation of religion and state. Public schools should become public spheres which are free from religious interests. Like other secular countries ${ }^{24}$, there will be always connection between the Japanese policy of the separation of religion and state and the prohibition of religious education in public schools.

Article 15 of the Basic of Education, point 2, in essence is similar to that of article 20 of the Japanese Constitution in regard to RE. However, the presence of article 15 of Basic of Education, point 1, is to accommodate social situation in which intersection of religion and school cannot be avoided. In fact, it is difficult to apply a strict interpretation of article 15, point 2, with regard to social reality in Japan. The presence of article 15, point 1 , is to give room to interpret and apply point 2 in a different way. In practice, teachers in Japan are difficult to teach the history of Japan without referring to Shinto or Buddhism, and they also have difficulties to "inculcate good behaviour without mentioning religiously traditional tales." ${ }^{25}$ For this reason, government released article 15, point 1 , in order to give room for the intersection between religion and school. It suggests to practice religious tolerance, to have general knowledge of religion, and to respect the position of religion in social life. This means that public education is not purely sterile from religion, not in the form of formal religious teachings of certain religion, but in the form of general knowledge. In fact, to free public education from religion is impossible, because the history of Japan somehow connects to Shinto and Buddhism. In Japan there are popular words to show Japanese religion, "born as Shinto, married as Christian, and die as Buddhist." Thus, intersection of public schools and religion in Japan is acknowledged.

The above explanation shows different supports of state to RE.

${ }^{24}$ Some countries that are based on secular ideology always prohibited religious education in public schools, see for examples, United State, South Korea, Mexico, Uruguay, Cuba, Azerbaijan and Kazakhstan.

25 Takahata, "Religious Education in Japan", p. 182. 


\section{Agus Nuryatno}

In Indonesia RE receives a strong support from the state, and this can be seen through the inclusion of three articles on RE in the bill of RI no. 20 year 2003 and six chapters and fifty articles in the Government Regulation no. 55 year 2007. In contrast to Japan, the state gives low support to RE, and this can be seen from the fact that RE is only mentioned once in the Japanese Constitution and once in the Basic Act of Education, 2006. This fact needs more explanation and exploration from different perspectives. The first explanation can be given by looking at the state's ideology. Indonesia is based on Pancasila that has religious nuance through the first principle, belief in one God, while Japan is based on secular ideology that holds the separation of state and religion. The choice of ideology as the foundation of the state contributes to what extent a state gives support to RE. The reason of why Indonesia and Japan have different support to RE is clearly due to different ideologies: non-secular and secular ideology.

The second reason lies in the interests of family and state. Families and the state of Indonesia see RE as an important part of people's life, while family and the state of Japan see RE in a different way. For the average of Indonesian families, the existence of RE in schools is to ensure that children receive appropriate religious teachings by which they can live based on religious values. The role of religious education is to transfer, maintain, and perpetuate religious values from one generation to another. The state, on the other hand, has two interests in religious education: on one hand, the state receives maximum political support from the people, and on the other, religious education has contribution to create ethical and civilized citizens. In Families and the state of Japan show a little interest in $\mathrm{RE}$, for which $\mathrm{RE}$ receives low support in the constitution and in public life.

The last argument presented in this work is about the type of society. Indonesia is multicultural society in terms of religions, ethnicities, and languages; while Japan is mono-cultural society in terms of above factors. Indonesia needs RE because it can promote tolerant, peace, and mutual understanding of one faith to the others. ${ }^{26}$ In order to make $\mathrm{RE}$ is meaningful for multicultural and plural society, it is necessary for Indonesia to redefine and reconstruct RE, from merely dealing with one's

${ }^{26}$ Brenda Watson highlights three importance of RE for human life: (a) RE can make a very positive contribution to world peace; (b) RE can help students in the search for their own convictions; and (c) RE can protect students from being indoctrinated; Brenda Watson, Education and Belief (Oxford: Blackwell Publishers, 1987), pp. 104-47. 
own religion to those of others. ${ }^{27}$ In contrast, Japan does not stress the importance of RE because the country has homogenous society that is is more manageable than heterogenic society.

\section{History of $\mathrm{RE}$}

Indonesia and Japan have a different history of the issue of RE. $\mathrm{RE}$ had become the issue in Japan since the period of Meiji Restoration in $1868,{ }^{28}$ in line with the modernization of education in Japan. The Meiji constitution was modified in 1945 after the defeat of Japan in the second World War, and with regard to religion and RE it is particularly mentioned in article 20 of the Constitution ${ }^{29}$ which guarantees the people's religious freedom. In Japan, 1945 was a year of modification of the Constitution, including the position of RE in public and private schools. By contrast, the year 1945 when Indonesia's independence was declared RE was hotly debated. Since the inception, RE, and in particular, Islamic education, has been supported by the state, ${ }^{30}$ by including RE in national education curricula. ${ }^{31}$ However, the implementation of RE in Indonesia is dynamic, depended on the regimes which ruled the country. Generally speaking, the development of RE in Indonesia can be divided into three phases: Soekarno era (1945-1965), Soeharto era (1966-1997), and reformation era (1998 onwards).

${ }^{27}$ M. Agus Nuryatno, "Islamic Education in A Pluralistic Society", Al-Jami'ah: Journal of Islamic Studies, vol. 49, no. 2 (2011), pp. 411-31.

${ }_{28}$ Meiji Restoration (1868-1912) is the continution of Tokugawa period (1600-1868) in the history of Japan. The transition from Tokugawa to Meiji is often characterized by from early modern (kinsei) to modern (kindai), from lare feudal to modern institutions, from shogunal to imperial rule, and from isolation to integration in the world economy; Marius B. Jansen and Gilbert Rozman (eds.), Japan in Transition: From Tokugawa to Meiji (Princeton: Princeton University Press, 1986), p. 3.

29 See: topic on State Policy on RE.

${ }^{30}$ M. Agus Nuryatno, "Pendidikan Islam dalam Sistem Pendidikan Nasional", in Pendidikan Islam di Dunia Melayu: Perbandingan Malaysia dan Indonesia, ed. by Nishino Setsuo (Japan: Asian Cultures Research Institute, 2010), pp. 287-304.

31 It is important to note that Indonesia has two institutions that are responsible for holding education, namely Minister of Education and Culture, for general education, and Minister of Religious Affairs, for Islamic Education. The separation of education had been there since national educational system was established in order to accommodate nationalist Muslim voices on education and to reduce the tension between nationalist Muslim and nationalist secular on education; see Achmadi, "Dekonstruksi Pendidikan Islam sebagai Sub-Sistem Pendidikan Nasional”, in Guru Besar Bicara Mengembangkan Keilmuan Pendidikan Islam, ed. by Muntholi'ah, M. Rikza Chamami, and Abdul Rahman (Semarang: RaSail Media Group, 2010). 


\section{Agus Nuryatno}

Looking at history, Indonesia and Japan have different stories of RE. Since inception, there was no tension between RE and the state in Indonesia. In $1950 \mathrm{RE}$ was taught at elementary and junior and senior secondary of public schools. It was taught under condition there were at least ten pupils in the class and had permission from their parents. All matters related RE are under supervision and responsiblilty of the Minister of Religious Affairs. ${ }^{32}$ In 1952, RE was practiced differently, each region in Indonesia had different application of RE. The 1960 plenary meeting of MPRS (Temporary Consultative Assembly of People) declared that RE becomes subject that is should be thought in public schools, from elementary to higher education, under the condition that the parents allow their children to take that subject. ${ }^{33}$ In contrast, there was a tension between the state and Christianity schools in Japan. In 1872, the government established public schools of elementary and secondary levels and higher education level. It was in the period of Meiji Restoration when private schools were established where law, medicine, liberal arts, and religion were the subjects of teachings and learning. There were an increasing number of private schools when the government withdrew the prohibition of teaching Christianity in $1873,{ }^{34}$ and many Christian denominations established missionary schools. The expansion of missionary schools led the government to be more aware of their existence, because these schools instructed students to admire Tenno that has close relation to Shinto religion. In fact, according to the government, Tenno cannot be approached except through Shinto's principles. The government viewed that this action was beyond Christian schools' mission, and this is the reason why the government then separates education from religion. As a result, in 1889 all schools, whether public or private, were under government's supervision and were prohibited to teach religion at all. ${ }^{35}$

Thus, in the Meiji restoration period, the reason why the state did

32 This was a result of the joint decree between Minister of Religious Affair, Prof. Mahmud Yunus, and Minister of Education and Culture, Mr. Hadi, in 1950. See, H.A. Mustafa and Abdullah Aly, Sejarah Pendidikan Islam di Indonesia (Bandung: Pustaka Setia, 1999), pp. 124-25.

33 Redja Mudyahardjo, Pengantar Pendidikan: Sebuah Studi Awal tentang Dasar-Dasar Pendidikan pada Umumnya dan Pendidikan di Indonesia (Jakarta: Raja Grafindo Persada, 2002), p. 422.

${ }^{34}$ Bunkacho Bunka-Bu Shu'umu-Ka, Religions History of 100 Years Since Meiji Restoration (Japan: Cultural Affairs Agency, 1983), p. 3.

35 Ibid., pp. 236-38. 
not support RE was because of the issue of Tenno that somehow is related to Shinto religion. In contrast to Indonesia, in the period of Soeharto regime (1966-1997), RE was supported by the state. In the beginning of his administration, the state was faced two types of extremists: on one hand, communism (anti-religion), as a left extremist, and on the other, radical Muslims who want to establish an Islamic state of Indonesia. One of the ways to face these challenges was by applying RE in schools, and made it as compulsory subject for all students, from elementary to higher education. RE in this context has two missions: first, to prevent students from the influence of communism, a state common enemy; and secondly, to show that the state supported the existence of religion. ${ }^{36}$ From this perspective it is possible to argue that RE was used by Soeharto's regime to oppose communism, in one hand, and to oppose radical religious belief which possibly lead to the effort of establishing an Islamic state.

Another issue that can be compared in terms of history of RE in Indonesia and Japan is about RE in public and private schools. In Indonesia, the requirement of RE was only in public schools, but after the release of bill no. 2 Year 1989 about the National Education System ${ }^{37}$, $\mathrm{RE}$ is compulsory in both public and private schools, from elementary to higher education. However, private schools with the basis of certain religion have no obligation to hold religious education of other religions. This policy was strengthened by the release of the government regulation no. 29/1990 which states that school which is based on certain religion was not obliged to teach ohter religions. ${ }^{38}$ In contrast, Japan history

${ }^{36}$ M. Mujiburrahman, "State Policies on Religious Diversity in Indonesia", Al-Jami'ah: Journal of Islamic Studies, vol. 46, no. 1 (2008), pp. 101-23.

37 To know more about the process of making this bill, please refers to Muhammad Sirozi, Politik Kebijakan Pendidikan di Indonesia: Peran Tokoh-Tokoh Islam dalam Penyusunan UUNo. 2/ 1989 (Jakarta: INIS, 2004). According to Mudyahardjo, in the early 1980s, couple years before the national curriculum of 1984 was released, there was a suggestion to include religious comparative curricula as part of the national curriculum in senior high school, but it was rejected by some Muslim groups, arguing that it could weaken the faith of the students; see: Mudyahardjo, Pengantar Pendidikan, p. 459.

${ }^{38}$ Many objections raised by Muslim groups, arguing that in fact, many Christian schools have more Muslim students than Christian. These Muslim students would not get Islamic religious education for years, and this would weaken their faith. As a matter of fact, some Catholic schools even asked the parents to sign a paper that allowing their Muslim children to follow Catholic religious education as their Catholic friends. In contrast, most of Christian people showed their agreement to this bill, because it accommodated community's right. Holding an education based on certain religion was part of the right of religious community. Thus, the right of student to receive religious Al-Jāmi'ah, Vol. 52, No. 2, 2014 M/1435 H 


\section{Agus Nuryatno}

shows different stories of RE. In the early of Meiji Restoration (1872), private schools held authority to teach RE, but in 1889 the government prohibited all schools--whether public or private--to teach religion and even the government proclaimed the separation of state and religion. Since 1945, religious education was allowed only in private schools, but not in public schools, and Shinto elements in schools' teaching were removed.

In terms of the relation between state and particular religion, Indonesia and Japan show different stories. The majority of Indonesian people belong to Islam, and the majority of Japanese are associated with Shinto, although not as true believers. In Indonesia, the state fully supports the existence of RE, and to certain degree, gives advantages to Islamic religion. ${ }^{39}$ Compared to Japan, the support of the state to Shinto is unclear due to the decision of separating the state from religion. However, in 1890, Tenno issued a document on moral education entitled Imperial Rescript on Education (Kyouiku Choku-go). The document contains the loyalty and filial piety of Japanese to traditional morality. But this document was claimed not to have any religious ingredient. This claim is not fully true, because the document was made by Tenno, and Tenno was strongly associated with Shinto. Thus, moral education that was issued and implemented in many schools was somewhat contains

education of his/her own faith can only be applied in public schools, not private schools. For further discussion, please refers to Listia, Arham, and Gogali, Problematika Pendidikan Agama di Sekolah, p. 149.

39 The Bill No. 20 Year 2003 about National Education System, as a revision of the Bill No. 2 Year 1989, and the Government Regulation No. 55 Year 2007 show clearly the support of the state to Islam. Many articles on RE give advantages to Muslim groups, and on the other hand, gives disadvantages for non-Muslim groups, in particular Christian schools. With these articles Muslim students have the right to receive religious education based on Islamic teachings and taught by a teacher of the same faith, even though they enroll at Christian schools. While for Christian groups, these articles are against the right of community to hold education based on the faith of that community. People who are coming to this kind of schools should follow rules and regulations made by these schools; otherwise community's right is not respected. It is also almost impossible for Christian schools to provide religious teachers for Muslim students, not only in terms quantity but also quality. Some Christian schools guaranteed that there will not be happened a conversion of Muslim student to Christianity because he/she enrolled to that Christian school. In practical level, these articles are not well implemented, and so far, there is no sanction from the government for those schools that do not follow these articles. 
ingredients of Shinto teachings. ${ }^{40}$ In 1935, the government allowed schools to give education based on religious sentiments. Does it mean that religious education was allowed? The answer is however no, as religious education is still prohibited. At this point, it is hard to differentiate between "education based on religious sentiments," that was allowed, and "religious education," that was prohibited. Looking at the context of education based on religious sentiments which is allowed, it seems that it is under the influence of Western thought and method of education that led many workers and students to be involved in socialist movement. To counter this movement, the government allowed education based on religious sentiments, and these religious sentiments refer to Shinto teachings. Religious education, on the other hand, is still prohibited in public schools, because it commands explicitly certain religion which is against the principle of the separation of religion and state. However, the situation changed in 1945 in line with the political turmoil of the Japan's defeat, the Meiji Constitution was modified. The Imperial Rescript on Education that was formulated by Tenno was abolished, and consequently, Shinto elements in school teaching were removed. ${ }^{41}$ At the same time, private schools were allowed to hold religious education.

\section{RE in Schools}

Once again, Indonesia is supportive to RE, and not only is RE permitted but also it is required, in public or private schools. In bill of Republic of Indonesia number 20 year 2003 dealing with National Education System, article 12, Point 1 (a) states "Each student in the unit of education has rights to: (a) receive religious education in his/her own faith and taught by a teacher of that faith." This means that all students hold right to receive RE in public and private schools. In contrast, in Japan, based on the Basic Act on Education of 2006, article 15, paragraph 2, $\mathrm{RE}$ is prohibited in public schools. It states, "The schools established by the national and local governments shall refrain from religious education or other activities of a specific religion." This article clearly prohibited religious education in public schools in order to make schools neutral in religion.

In Indonesia, all students should receive RE, from elementary to higher education, and schools have obligation to provide it. However, the

${ }^{40}$ Listia, Arham, and Gogali, Problematika Pendidikan Agama di Sekolah, pp. 234-35.

${ }^{41}$ Ibid., pp. 408-10.

Al-Jāmiah, Vol. 52, No. 2, 2014 M/1435 H 


\section{Agus Nuryatno}

amount of hours is different from one school to another; it depends on what of type of school, wheter it is public school, madrasab (Islamic public school), private school, or religious-based private school. Elementary students in public schools receive four hours of RE per-week, while for elementary students of madrasah receive six hours per-week. Students of secondary junior and senior of public schools receive three hours perweek, and the same is so for madrasah. In higher education, RE is taught two credits. ${ }^{42}$ Since Islam is not the ideology of the state, the content of RE in schools is not only Islamic teachings, but also Christianity (Protestant and Catholic), Hinduism, Buddhism, and Confucianism. However, each religion is taught separately based on the faith of students and taught by teachers of the faith. Thus, there are many kinds of RE: RE for Islam, RE for Catholic, RE for Protestant, RE for Hinduism, and RE for Buddhism.

The case is different in Japan, although the regulation of education states clearly that government schools "shall refrain from religious education or other activities for a specific religion;" it does not mean that there is no connection at all between religion and school, because the government acknowledged the necessity of moral education based on religious thought. In 1949, the Ministry of Education issued some notes to public schools:

Visiting religious facilities with the aim of worship or participating in religious ceremony and festival is prohibited;

Visiting those facilities for academic or cultural purpose is allowed unless children are forced to go;

To use religious materials in a class is accepted for academic or educational purposes, except praising or denying a certain religion; and

School children are free to form religious groups in extracurricular activities. $^{43}$

Although religious education strictly prohibited in public schools, there are some intersections between religious elements and public schools in Japan. The first obvious intersection is in moral education. According to the guidelines of the government a class for moral education is aimed at encouraging zest for living. In practical level, the guidelines of moral education for elementary and secondary school levels emphasize "having a feeling of reverence for what is beyond the power of the human being as well as fostering friendship by trusting each other

42 The National Curriculum of 2013.

43 Takahata, "Religious Education in Japan", p. 183. 
and learning together, cooperating with the opposite sex in a friendly manner, respecting and having affection for parents and grandparents, and being willing to make commitments for the happiness of the family." 44 All students are required to take subject on moral education because it does not contain any denominational content. Another intersection is in the subject of ethics, a subject for high school level, but not it is obligatory. The guideline for this subject is to teach students basic ideas of the Christian, Buddhist, Confucian, and Muslim religions in addition to ancient Greek philosophy to aid them in understanding their human status. The third intersection is in history class, where religion is treated as historical fact in Japanese or the world history. Students should take Japanese history until secondary school level, while world history is taught in high school level.

Unlike public schools that are prohibited of RE, private schools, particularly those that have religious affiliation with certain religion, have freedom to hold religious education. Article 50, paragraph 2, and article 79 of the Ordinance for Enforcement of the School Education Act explains that private schools of elementary and secondary are allowed to hold religious education based on their affiliated religion as part of their regular curriculum. This means that RE is allowed to be taught at private schools in Japan. In fact, there are 115 high schools that are affiliated with Roman Catholic Church; 93 private high schools affiliated with Protestant; 5 high schools affiliated with Shinto; 108 high schools affiliated with Buddhist sects; and 16 high schools affiliated with newly developed religious sect. In total, private schools approved by the government and have religious affiliation are 25 percent of the total national number. ${ }^{45}$ Interestingly, the huge number of private high schools based on certain religion does not have any correlation with the growth number of certain believers in Japan. For example, private high schools based on Christianity that take 60 percent of total number of religious school did have little impact on the number of Christian believers in Japan. In 1980, the total number of Christian believers was one million, and after twenty six years, the number was three million. According to Takahata, there are two reasons as to why there is no connection between the number of religious schools and the number of religious believers. First, students who attend religious schools are mostly non-believers, and secondly, they choose to attend these schools not because of religious reason, but because of prestige,

${ }^{44}$ Ibid., p. 184.

45 Davis and Miroshnikova (eds.), The Routledge International Handbook, p. 186. 


\section{Agus Nuryatno}

reputation, or quality of these schools. They believe that these schools can help them to go to fine universities. ${ }^{46}$

\section{RE and Student Behaviours}

The last part of this paper is comparing the impact of RE on students' attitudes and behaviours. I would argue, however, that putting RE as solely variable of student behaviours can be trapped into simplification, because there are many variables that contribute to their attitudes and actions such as families, school culture, society, mass media, and so on. I am not going to judge that their behaviours are as a result of RE alone. The same simplification may also be made by neglecting the contribution of RE to students' behaviours, because the main intention of RE is how to improve students' life behaviours. RE in this context is not only seen from cognitive aspect, or as knowledge, but also as affective and psychomotor.

Comparing RE in relation to students' attitudes and actions in Indonesia and Japan is not an easy task. In Indonesia, there are many reports of students' violence occurring in secondary junior and senior high schools and some ended to death. The Indonesian Commission for Child Protection (KPAI) reported that: (1) in 2013, from January to October, there were 229 cases of student brawls and 19 of them caused death; (2) in 2012, there were 128 cases of student brawls, where 104 cases occurred in Jakarta that resulted in 17 deaths, 39 heavy injured, and 48 light injured; (3) in 2010, there were 800 cases on student violence in Indonesia. ${ }^{47}$ The violence usually took the form of brawl, throwing acid water, and bus hijack. The Jakarta Globe reported students violence, such as "'Disrespectful' Student dies After Beating," "School Suspect Bullying Death to Be Placed in Juvenile Home," "Jakarta Art Students Arrested Over Boarding House Assault," "Supreme Court Upholds Student Brawl Stabber's Sentence,"48 "Student Killed by Samurai Sword in School Brawl: Report", "Jakarta Students Attack with Acidic Solution", "Latest Acid Attack Highlights Disturbing New Trend." 49

46 Ibid., p. 187.

47 Amndra Mustika Megarani, "Modus Kekerasan Pelajar Meningkat", Tempo Metro (14 Dec 2011), http://www.tempo.co/read/news/2011/12/14/064371551/ Modus-Kekerasan-Pelajar-\%20Meningkat, accessed 16 Jul 2013.

48 "Jakarta Student Violence Archives", Jakarta Globe, http://thejakartaglobe. beritasatu.com/tag/jakarta-student-violence/, accessed 16 Sep 2013.

49 "Students Brawl Archives", Jakarta Globe, http://thejakartaglobe.beritasatu. $\mathrm{com} / \mathrm{tag} / \mathrm{students-brawl/,} \mathrm{accessed} 16$ Sep 2013. 
Many reports are also provided by other mass media in Indonesia about student's brawl, school bullying, and other forms of violence. To a certain degree, this shows that RE in Indonesia has little contribution to make students behave properly in line with the existing norms, on the ground that these students receive RE from elementary to secondary junior or senior high school. As mentioned earlier, RE is a mandatory subject that should be taught in all lines, levels, and types of education..$^{50}$ Still, RE is supported by the state in terms of policy and regulations, but its contribution to students' behaviours remains to questioned. The failure of RE to give good impact on students' behaviours raised criticisms. One of themis that the teaching of RE is too dominant in the aspect of cognitive, by emphasizing RE as knowledge through indoctrination and memorization. As a result, students know RE but do not know how to make it meaningful and applicable in their life, because RE is merely seen as "knowledge," not as fundamental values of life.

In contrast to Japan, it is difficult to find the news of student's brawl, violence, and school bullying. Students are discipline, hardworking, and follow the rules of schools. No report in mass media, social media, or television, concerning student's bullying or brawls. There is no violence can be seen either in schools or public life. The question is: does it caused by RE? I would argue that RE in Japan, like in Indonesia, has little contribution to make students behave properly in school or public life. Some arguments can be made here: first, not all students receive RE in schools, only those who enrol in private religious-based schools receive RE, and only 25 per cent of all private high schools approved by the government are religiously affiliated, ${ }^{51}$ secondly, students who attend public schools only receive small elements of religion through moral education, subjects of ethics, and history; third, most of students do not care about religion and the reason why they attend private religious-based schools is not because they interested in religion, but they believe that these schools can help them to go to good universities. ${ }^{52}$

I would argue the determinant factor that make Japanese students, in particular, and Japanese society, in general, are tolerance, respecting each other, hardworking, loyalty, helpful, and the like, are, not because of RE, but the old traditions that were based on Shinto's principles and had been inherited from one generation to another generation, especially

50 The Bill of RI Number 20 Year 2003

51 Takahata, "Religious Education in Japan", p. 106.

${ }^{52}$ Ibid., p. 187. 


\section{Agus Nuryatno}

started from Tokugawa reign and then continued down to the Meiji Restoration. The sublime values from the past had been maintained and handed on well from one generation to next generation. Although there was a change in society because of modernization and liberalization, the foundations of society remain firm. This is the reason why Japanese society has entered the modern world without losing their traditional identities and values.

\section{Concluding Remarks}

The implementation of RE depends on the state's policy, and the state's policy on RE is strongly influenced by the state's ideology. When secular ideology is chosen as the foundation of the state, RE is allowed only in private schools, not in public schools. The latter should be free from religious interferes and influences. In contrast, when Islam becomes the ideology of state, $\mathrm{RE}$ receives maximum support from the state to be taught in public and private schools. However, public schools can only have Islamic religious education, and this can be seen in Malaysia and Pakistan.

Indonesia and Japan are two different countries in terms of ideology. The former is based on Pancasila ideology, that is neither secular nor Islamic, but somewhere between the two; while Japan chooses secular ideology. The treatment of these two countries on RE is also different. The former strongly supports the existence of RE, in public and private schools, through policies and regulations; while the latter only allows RE in private schools, not in public schools, because public schools should refrain from any religious activities. ${ }^{53}$ Interestingly, the strong supports of the state to RE does not always give good impact on students' behaviour. In Indonesia, student brawls and violence are very often reported by mass media, and, the Indonesian Commission for Child Protection (KPAI) reports the brutality of some high schools students in Indonesia. From this perspective, RE has little contribution to help students behave properly in line with the existing religious values and norms. In contrast, in Japan, it is hard to find students of high schools behaving improperly by violating schools' rules. But, this does not mean because of RE regulation and policy, arguing that not all students receive $\mathrm{RE}$ when they are in schools. RE is only taught in private religious-based schools, and the percentage of these kinds of schools is only twenty five

53 The Basic Act on Education, 2006, Article 15. 
Comparing Religious Education in Indonesia and Japan percent. In Japan, the old traditional values that has been handed down from one generation to another generation since 17 centuries ago seems more powerful than RE in making students, in particular, and Japanese society, in general, to behave properly in line with the existing norms and values. 


\section{BIBLIOGRAPHY}

Achmadi, "Dekonstruksi Pendidikan Islam sebagai Sub-Sistem Pendidikan Nasional", in Guru Besar Bicara Mengembangkan Keilmuan Pendidikan Islam, ed. by Muntholi'ah, M. Rikza Chamami, and Abdul Rahman, Semarang: RaSail Media Group, 2010.

Burgess, Chris, “Multicultural Japan' Remains a Pipe Dream”, The Japan Times, 27 Mar 2007, http://www.japantimes.co.jp/ community/2007/03/27/issues/multicultural-japan-remains-apipe-dream/, accessed 16 Jan 2013.

Davis, Derek H. and Elen Miroshnikova (eds.), The Routledge International Handbook of Religious Education, New York: Routledge, 2013.

Grimmitt, Michael, Religious Education and Human Development: The Relationship between Studying Religions and Personal, Social and Moral Education, Great Britain: McCrimmons Publishing, 1987.

Hashim, Rosnani, "Religious Education in Malaysia", in The Routledge International Handbook of Religious Education, ed. by Derek H. Davis and Elen Miroshnikova, New York: Routledge, 2013.

Hellwig, Tineke and Eric Tagliacozzo (eds.), The Indonesia Reader: History, Culture, Politics, Durham: Duke University Press, 2009.

"Indonesia Population 2013", World Population Statistics, 12 Jun 2013, http://www.worldpopulationstatistics.com/indonesiapopulation-2013/, accessed 18 Feb 2014.

"International Religious Freedom Report for 2013", U.S. Department of State, 15 Sep 2013, http://www.state.gov/j/drl/rls/irf/ religiousfreedom/index.htm, accessed 18 Feb 2014.

"Jakarta Student Violence Archives", Jakarta Globe, http:/ / thejakartaglobe. beritasatu.com/tag/jakarta-student-violence/, accessed 16 Sep 2013.

Jansen, Marius B. and Gilbert Rozman (eds.), Japan in Transition: From Tokugawa to Meiji, Princeton: Princeton University Press, 1986.

“Japan Population 2013”, World Population Statistics, 27 Sep 2013, http:// www.worldpopulationstatistics.com/japan-population-2013/, accessed 18 Feb 2014.

Khan, Khalil-ur-Rehman and Qaisar Javed Mian, "Religious Education in Pakistan", in The Routledge International Handbook of Religious Education, ed. by Derek Davis and Elena Miroshnikova, New York: 
Comparing Religious Education in Indonesia and Japan

Routledge, 2013.

Kyodo, "Aso Says Japan is Bation of 'One Race", The Japan Times Online, 18 Oct 2005, http://www.japantimes.co.jp/news/2005/10/18/ national/aso-says-japan-is-nation-of-one-race/, accessed 16 Jan 2013.

Listia, Laode Arham, and Lian Gogali, Problematika Pendidikan Agama di Sekolah: Hasil Penelitian tentang Pendidikan Agama di Kota Jogjakarta 2004-2006, Yogyakarta: Dian Interfidei, 2004.

Megarani, Amndra Mustika, "Modus Kekerasan Pelajar Meningkat", Tempo Metro, 14 Dec 2011, http://www.tempo.co/read/ news / 2011/12/14/064371551/Modus-Kekerasan-Pelajar-\%20 Meningkat, accessed 16 Jul 2013.

Mudyahardjo, Redja, Pengantar Pendidikan: Sebuab Studi Awal tentang DasarDasar Pendidikan pada Umumnya dan Pendidikan di Indonesia, Jakarta: Raja Grafindo Persada, 2002.

Mujiburrahman, M., "State Policies on Religious Diversity in Indonesia", Al-Jami'ah: Journal of Islamic Studies, vol. 46, no. 1, 2008, pp. 101-23 [http://dx.doi.org/10.14421/ajis.2008.461.101-123].

Mustafa, H.A., and Abdullah Aly, Sejarah Pendidikan Islam di Indonesia, Bandung: Pustaka Setia, 1999.

Nuryatno, M. Agus, "Islamic Education in A Pluralistic Society", AlJami'ah: Journal of Islamic Studies, vol. 49, no. 2, 2011, pp. 411-31 [http://dx.doi.org/10.14421/ajis.2011.492.411-431].

----, "Pendidikan Islam Dalam Sistem Pendidikan Nasional", in Pendidikan Islam di Dunia Melayu: Perbandingan Malaysia dan Indonesia, ed. by Nishino Setsuo, Japan: Asian Cultures Research Institute, 2010.

Ricklefs, Merle Calvin, A History of Modern Indonesia Since c.1200, 4th edition, Stanford: Stanford University Press, 2008.

Shu'umu-Ka, Bunkacho Bunka-Bu, Religious History of 100 Years Since Meiji Restoration, Japan: Cultural Affairs Agency, 1983.

Sirozi, Muhammad, Politik Kebijakan Pendidikan di Indonesia: Peran TokohTokoh Islam dalam Penyusunan UU No. 2/ 1989, Jakarta: INIS, 2004.

"Students Brawl Archives", Jakarta Globe, http://thejakartaglobe. beritasatu.com/tag/students-brawl/, accessed 16 Sep 2013.

Takahata, Eiichiro, "Religious Education in Japan", in The Routledge International Handbook of Religious Education, ed. by Derek H. Davis 
M. Agus Nuryatno

and Elena Miroshnikova, New York: Routledge, 2013.

Taylor, Jean Gelman, Indonesia: Peoples and Histories, New Haven: Yale University Press, 2003.

Watson, Brenda, Education and Belief, Oxford: Blackwell Publishers, 1987. 